\title{
PENDIDIKAN MODERASI ISLAM KH. ASEP SAIFUDDIN CHALIM; MENCEGAH RADIKALISME AGAMA DAN MEWUJUDKAN MASYARAKAT MADANI INDONESIA
}

\author{
Syaikhu Rozi \\ Program Studi Pendidikan Agama Islam, Universitas Islam Majapahit \\ Email. Syaikhurozi418@gmail.com
}

\begin{abstract}
This study uses the research design of the Individual Life History Case Study by Imam Suprayogo and Tobroni. The study was Done to reveal the life history of $\mathrm{KH}$. Asep Saifuddin Chalim, his struggles, careers, dedication, thoughts and works related to education of Islamic moderation. The data analysis technique uses Spradley's naturalistic research steps whose overall process concludes including: 1) Prevention of religious radicalism through education is carried out by implementing quality education in accordance with Islamic principles of aswaja and by emphasizing more responsibility for teachers not only to teach, but also supervises and accompanies students inside and outside the classroom so as to make it the spearhead in maintaining, preserving and grounding the existence of aswaja teachings. Responsibility is carried out with a nurturing and education approach (andragogy). 2) Civil society is a civil which always doing the process of searching for identity and guarantees the freedom of individuals to growing up so that they have the ability and opportunity to build a culture of civic citizenship. This is formed by implementing an education system based on cultural elements that consider ethics, aesthetics and religiosity so that young intellectuals have the toughness and excellence which is the starting point for building civil society.
\end{abstract}

Keywords: Moderation of Islam, Religious Radicalism, Civil Society

\section{PENDAHULUAN}

Menurut sejarah, Rosululloh Muhammad Saw menerima wahyu saat berusia 40 tahun pada bulan Ramadhan tanggal 26/27 yang bertepatan dengan tahun 610 menurut kalender Kristen. ${ }^{1}$ Wahyu pertama diperoleh di Gua Hira dan terus berlangsung selama 23 tahun sampai la meninggal pada 4 juni 632 . Wahyu-wahyu yang diperoleh kemudiaan dibukukan oleh para sahabatnya dalam sebuah mushaf alQur'an setelah la meninggal, dimana ayat-ayatnya dapat membimbing para sahabat dan umat islam yang jumlahnya secara perlahan terus bertambah banyak melalui perjalanan waktu yang menakjubkan. ${ }^{2}$

${ }^{1}$ David Levering Lewis, The Greatness of Al-Andalus; Ketika Islam Mewarnai Peradaban Barat. Terjemah Yuliani Liputo (Jakarta: PT. Serambi IImu Semesta, 2012), hal. 72

${ }^{2}$ Mustafa Akyol, Islam Tanpa Ekstremisme; Potren Seorang Muslim untuk Kebebasan (Jakarta: PT. Elex Media Komputindo, 2014), hal. 22 
Demikian, al-Qur'an menjadi inti ajaran Islam dan menjadi sistem ide yang muncul dari pengalaman sejarah panjang, yaitu pengalaman pewahyuan dalam sejarah, penerapannya dalam kenyataan dan penyesuaian kembali menurut kemampuan manusia. ${ }^{3}$ Karenanya al-Qur'an telah memasuki kehidupan sosial manusia dengan banyak tambahan doktrin, aturan-aturan, dan perilaku-perilaku yang semuanya terangkai dalam penafsirannya. ${ }^{4} \mathrm{Hal}$ itulah yang menjadi latar belakang perbedaan-perbedaan penafsiran terhadap al-Qur'an, termasuk juga terhadap assunnah sebagai sumber primer kedua ajaran Islam setelah al-Qur'an.

Sehubungan dengan perbedaan penafsiran terhadap al-Qur'an dan juga terhadap as-Sunah, Islam secara umum terbelah diantara tiga gerakan pemikiran yang masing-masing memiliki corak dan karakteristik yang berbeda-beda. Tiga gerakan Islam yang dimaksud adalah fundamental, liberal, dan moderat. Dalam konteks Islam Indonesia, dua gerakan yang disebut di awal, diyakini tidak sesuai dengan karakter bangsa Indonesia yang telah memilih Pancasila sebagai dasar ideologi. Hal itulah yang mendorong perlunya pandangan Islam yang moderat sebagai pilihan yang tepat dan terbaik bagi Indonesia yang multikultural. ${ }^{5}$

Istilah Islam moderat atau yang kadang disebut moderasi Islam, merujuk pada kata ummatan wasatan yang terdapat di dalam Al-Qur'an surat Al-Baqarah [2] ayat 143. Dalam ayat al-Qur'an tersebut, Umat Islam diklaim sebagai umat pilihan atas perannya sebagai saksi yang adil terhadap perbuatan orang yang menyimpang dari kebenaran. ${ }^{6}$ Peran tersebut didapatkan oleh muslim moderat diantaranya karena mereka adalah orang-orang yang memiliki keyakinan yang benar terhadap Islam, mengimani dan merealisasikan 5 rukun Islam, menerima warisan tradisi Islam namun sekaligus memberikan modifikasi-modifikasi dalam aspek tertentu darinya demi mewujudkan tujuan-tujuan moral yang utama dari keyakinan tersebut. ${ }^{7}$

Term wasatan pada Qs. Al-Baqarah [2] ayat 143 tersebut kemudian digunakan dalam beberapa istilah seperti "moderasi dalam Islam", "Islam moderat" dan juga "Islam wasathiyyah". Selanjutnya istilah tersebut dijadikan terminologi bagi kajian yang membahas jalan tengah dalam Islam berdasarkan proyeksi al-Qur'an yang

\footnotetext{
${ }^{3}$ Hasan Hanafi, Cakrawala Peradaban Global; Revolusi Islam untuk Globalisme, Pluralism dan Egaliterisme Antar Peradaban, terjemah Muhammad Saiful Anam (Yogyakarta: IRCiSoD, 2003), hal. 36

${ }^{4}$ Mustafa Akyol, op.cit., hal. 8

${ }^{5}$ Moh. Mahfudz MD., Penguatan Moderasi Islam dalam Konteks Berbangsa dan Bernegara; Tinjauan Aspek Hukum dan Konstitusi. Makalah disampaikan pada $2^{\text {nd }}$ Annual Conference for Muslim Scholerss (AnCoMS) Kopertais Wilayah 4 Surabaya, pada tanggal April 2018 di UIN Sunan Ampel Surabaya.

${ }^{6}$ Departemen Agama RI, Al-Quran dan Terjemahnya (Surabaya: Al-Hidayah, 1998), hal. 36

${ }^{7}$ Khaled Abou Al Fadl sebagaimana yang dikutip oleh Ismail, Pesantren, Islam Moderat dan Etika Politik dalam Perpsektif Pendidikan Islam. Prosiding $2^{\text {nd }}$ Annual Conference For Muslim Scholerss (AnCoMS) Kopertais Wilayah 4 Surabaya tahun 2018, hal. 588
} 
menyangkut identitas diri dan pandangan dunia komunitas muslim untuk menghasilkan kebajikan yang membantu terciptanya harmonisasi sosial dan keseimbangan dalam kehidupan individu, keluarga, masyarkat maupun hubungan antar manusia yang lebih luas. $^{8}$

Dalam konteks pergerakan Islam di Indonesia, kelompok Islam moderat merujuk pada kelompok Islam yang mengambil posisi tengah antara dua pergerakan Islam fundamentalisme-radikal dan liberalis-sekuler. Pergerakan yang dimaksud adalah Nahdlotul Ulama (NU) yang dalam interaksi sosio-kultural memiliki watak dan karakter tawassut (moderat), tasammuh (toleran) dan tawazun (harmoni). ${ }^{9}$

Namun, sebagai sebuah produk ijtihad yang belum menyediakan petunjuk pelaksanaan dan petunjuk teknis (juklak dan juknis)-nya, implementasi konsep moderasi Islam dalam kehidupan sehari-hari ternyata sering menemui persoalan. Bahkan bagi para guru, aktualisai konsep moderasi Islam di dunia nyata tidak jarang juga menghadapi kendala, yaitu ketika konsep-konsep tersebut harus diajarkan kepada anak di sekolah/madrasah, karena belum ada rumusan konsep pendidikan yang baku tentang bagaimana moderasi Islam harus diajarkan kepada peserta didik.

Dalam konteks ini, diperlukan sebuah rumusan konsep pendidikan yang dapat diimplementasikan secara praktis di lapangan agar relevansi moderasi Islam dalam kehidupan sehari-hari di masyarakat dapat diupayakan secara maksimal sehingga Islam dapat benar-benar menjadi agama yang membawa rahmat bagi seluruh umat manusia. Belum adanya rumusan yang dimaksud merupakan persoalan yang perlu segera dicari jawabannya melalui serangkaian kegiatan penelitian dan pengkajian.

Namun jawaban terhadap persoalan tersebut harus dihasilkan dari seseorang atau entitas tertentu yang memiliki otoritas dalam bidang kelslaman dan ilmu pendidikan, seperti halnya dari seorang kyai yang merupakan ulama pewaris risalah kenabian (warosatu al-anbiya'). Sehubungan dengan hal tersebut, penelitian ini dilakukan terhadap KH. Asep Saifuddin Chalim, Pendiri sekaligus Pengasuh Pondok Pesantren dan Madrasah Bertaraf Internasional Amanatul Ummah Pacet Mojokerto.

\footnotetext{
${ }^{8}$ Azumardi Azra dalam "Moderasi Islam", yang dinyatakan dalam kolom Resonansi Republika.co.id 17 Desember 2015. Dengan merujuk pada penjelasan Hashim Kamali dalam The Middle Path Of Moderation In Islam; The Quranich Principle Of Wasatiyyah (New York: Oxford University Press, 2015), hal. 1-2. Dikutip oleh Jasminto, Urgensi Teori Andragogy dalam Memperkuat Visi Moderat Islam di Indonesia, Prosiding $2^{\text {nd }}$ Annual Conference For Muslim Scholerss (AnCoMS) Kopertais Wilayah 4 Surabaya tahun 2018, hal. 645

${ }^{9}$ Muhammad Tholhah Hasan dalam Ismail, Pesantren, Islam Moderat dan Etika Politik dalam Perpsektif Pendidikan Islam. Prosiding $2^{\text {nd }}$ Annual Conference for Muslim Scholerss (AnCoMS) Kopertais Wilayah 4 Surabaya tahun 2018, hlm. 588
} 


\section{METODE PENELITIAN}

Penelitian ini merupakan penelitian lapangan/empiris (field research), dilakukan secara kualitatif dengan menggunakan desain penelitian Studi Kasus Sejarah Hidup Individu yang mengikuti pendapat Imam Suprayogo dan Tobroni. ${ }^{10}$ Berdasarkan desain tersebut, peneliti mengkaji sejarah hidup tokoh pendidikan yang terkenal, yaitu KH. Asep Saifuddin Chalim, sebagai pelaku dan aktor pendidikan yang kiprahnya bersifat menyejarah.

Dengan demikian, penelitian ini pada prinsipnya dilakukan untuk mengungkap sejarah hidup $\mathrm{KH}$. Asep Saifuddin Chalim, lingkungan sosial, pergumulan, karier, pengabdian, pemikiran-pemikiran serta karya-karyanya yang terkait dengan pendidikan moderasi Islam. Kajian terhadap hal tersebut dalam penelitian ini dilakukan secara kritis, skeptis dan analisis, serta berdasarkan fakta-fakta yang sesuai dengan akal sehat. Adapun beberapa alasan kenapa KH. Asep Saifuddin dipilih sebagai subyek dan obyek penelitian ini yaitu:

1. KH. Asep Saifuddin Chalim adalah seorang tokoh pendidikan moderasi Islam yang memiliki ikatan geneologis, struktural dan fungsional dengan Organisasi Islam Moderat di Indonesia yaitu Nahdlotul Ulama. ${ }^{11}$

2. Merupakan tokoh pendidikan moderasi Islam yang masih hidup hingga tulisan ini ditulis. Walaupun, tokoh yang menjadi obyek penelitian masih hidup, penelitian dapat dilakukan terhadapnya karena yang menjadi obyek penelitian studi tokoh bisa tokoh yang masih hidup ataupun tokoh yang sudah meninggal, namun memiliki sejumlah karya yang dapat digali melalui proses penelitian. ${ }^{12}$

3. Menurut Syahrin Harahap (2006) ketokohan seseorang yang menjadi obyek studi tokoh dapat dilihat dari 3 indikator, yaitu: a) Integritas tokoh tersebut, yang dapat dilihat dari kedalaman ilmunya, kepemimpinannya, keberhasilannya dalam bidang yang digeluti, hingga memiliki kekhasan atau kelebihan dibanding orang-orang segenerasinya. Integritas tokoh juga dapat dilihat dari sudut integritas moralnya. b)

\footnotetext{
${ }^{10}$ Imam Suprayogo dan Tobroni, Metodologi Penelitian Sosial Agama (Bandung: PT. Remaja Rosda Karya, 2001), hlm. 140.

${ }^{11}$ Ikatan geneologis, KH. Asep Saifuddin Chalim dengan NU berakar dari keberadaan beliau sebagai salah satu putra pendiri NU, yaitu Kyai Abdul Chalim yang merupakan komunikator kunci lahirnya NU. Hubungan $\mathrm{KH}$. Asep Saifuddin Chalim dengan NU yang bersifat struktural karena beliau merupakan mantan Ketua Tanfidziyah NU ranting Siwalankerto pada tahun 1982-1985, Ketua MWC NU Wonocolo satu periode (1985-1990), Ketua Tanfidziyah NU Cabang Surabaya pada tahun 1990-2000 dan sampai sekarang menjabat Ketua Pimpinan Pusat (PP). PERGUNU.Adapun hubungan KH. Asep Saifuddin Chalim dengan NU yang bersifat fungsional adalah karena beliau merupakan warga NU yang selalu mendedikasikan hidupnya untuk menjaga eksistensi Islam ahlus sunnah wal jama'ah sebagaimana ajaran NU. Syaikhu Rozi, Pendidikan Moderasi Islam Menurut KH. Asep Saifuddin Chalim. Laporan Akademik Bantuan Penelitian Diktis Kemenag RI Tahun 2018, FAI Universitas Islam Majapahit. 2006), hlm. 10

${ }^{12}$ Syahrin Harahap, Metodologi Studi Tokoh Pemikiran Islam (Jakarta: Istiqamah Mulya Press,
} 
Karya-karya monumental. Karya tersebut dapat berupa karya tulis, karya nyata dalam bentuk fisik dan non fisik yang bermanfaat atau pemberdayaan manusia, baik sezamannya maupun masa sesudahnya. c) Kontribusi (jasa) atau pengaruhnya yang terlihat atau yang dirasakan secara nyata oleh masyarakat baik dalam bentuk pikiran, maupun kepemimpinan dan keteleladanannya sehingga ketokohannya diakui, diidolakan, diteladani dan dianggap memberikan inspirasi bagi generasi sesudahnya. ${ }^{13}$

Pengumpulan data penelitian ini dilaksanakan dengan wawancara mendalam (indepth interview) dan studi dokumentasi. Sedangkan analisa data dilakukan dengan cara mereduksi, mentrianggulasi dan mengevaluasi data yang telah diperoleh secara kritis, serta menguji relevansinya berdasarkan teori-teori yang relevan. Adapun langkah-langkahnya menggunakan langkah-langkah penelitian naturalistik sebagaimana yang dikemukakan oleh Spradley. dimana proses pelaksanaannya terdiri atas 4 tahap, yaitu: 1) analisa domein, 2) analisis taksonomi, 3) analisis komponen, dan 4) analisis tema. Jika digabungkan dengan proses pengumpulan data, maka analisa data dengan Model Spradley meliputi 7 tahap, yaitu: 1) pengamatan deskriptif, 2) analisa domein, 3) pengamatan terfokus, 4) analisis taksonomi, 5) pengamatan terpilih, 6) analisis komponensial dan diakhiri dengan 7) analisis tema. Proses tersebut dapat digambarkan dengan lingkaran siklikal sebagai berikut: ${ }^{14}$

\section{Gambar I}

\section{Analisa data dengan Model Spradley}

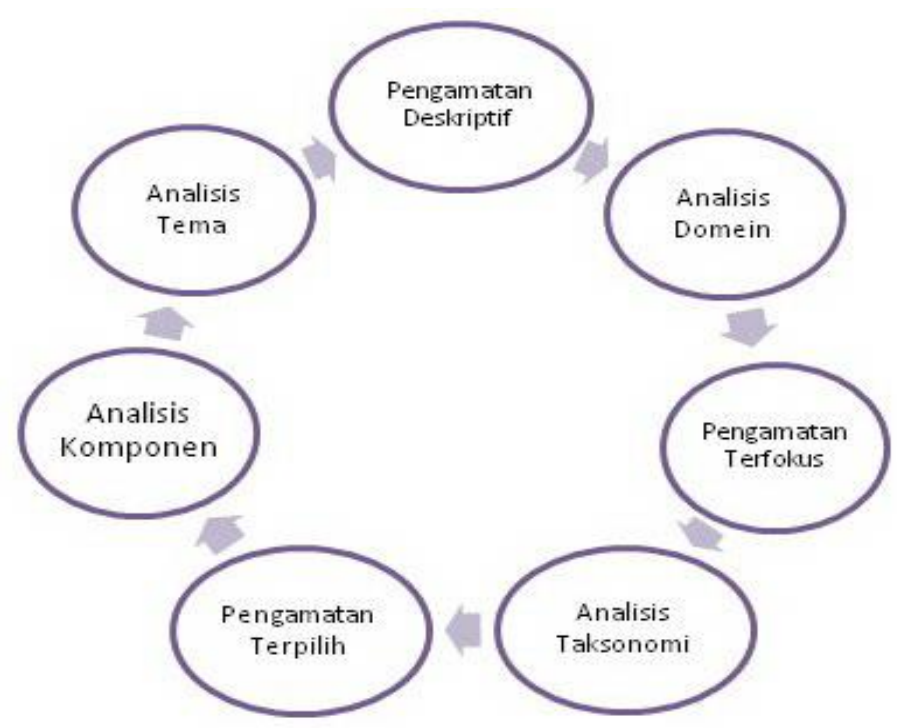

${ }^{13}$ Syahrin Harahap, ibid., hlm. 9

${ }^{14}$ Leksi J. Moloeng, Metode Penelitian Kualitatif (Bandung: Remaja Rosdakarya, 2000), hlm. 
Pengecekan keabsahan data penelitian dilakukan dengan triangulasi. Dengan model tersebut, penulis akan meng-crosscheck temuan dengan membandingkan berbagai sumber, metode atau teori, serta dengan cara mengajukan berbagai variasi pertanyaan, mengecek berbagai sumber data, memanfaatkan berbagai metode agar pengecekan keabsahan data dapat dilakukan.

\section{HASIL PENELITIAN DAN PEMBAHASAN}

\section{A. Pendidikan Moderasi Islam untuk Pencegahan Radikalisasi agama Melalui}

Dalam realitas sosial dan politik Negara yang menggunakan demokrasi sebagai sistemnya, aliran dan keyakinan keagamaan akan banyak bermunculan dengan mudah, termasuk diantaranya aliran-aliran dalam keberagamaan Islam. $\mathrm{Hal}$ itu karena negara-negara yang menganut demokrasi akan menjamin kebebasan warga negaranya untuk mendirikan aliran-aliran keagamaan yang dapat mewadahi pemikiran, sikap dan perilaku-perilaku keberagamaan para penganutnya.

Diantara aliran-aliran keagamaan Islam yang muncul dan berkembang di Indonesia, sebagian diantaranya ada yang moderat dan sesuai dengan akidah ahlus sunnah wal jama'ah. Namun tidak dapat dipungkiri sebagian lainnya ada juga yang "sesat" dan bertentangan dengan akidah ahlus sunnah wal jama'ah yang moderat.

Menurut KH. Asep Saifuddin Chalim, keberadaan aliran keagamaan, khususnya aliran-aliran yang sesat merupakan ancaman serius bagi eksistensi ajaran ahlus sunnah waljama'ah. Sebagian orang bahkan warga nahdliyin bisa jadi akan terpengaruh dan mengikuti aliran tersebut karena beberapa faktor. Beliau mengatakan:

Aliran keagamaan, utamannya aliran-aliran yang sesat, merupakan ancaman serius bagi eksistensi ajaran ahlus sunnah waljama'ah, karena itu harus diwaspadai. Di dalam sebuah hadits disebutkan bahwa "kada al-faqru an yakuna kufron (hampir saja kefakiran itu menjerumuskan seseorang pada kekafiran)". Fakir dalam konteks ini dapat diperluas menjadi fakir dari aspek ekonomi dan fakir dari aspek ilmu. Realitas mengatakan bahwa orang-orang yang terpengaruh dan mengikuti aliran-aliran tertentu (yang bertentangan dengan ahlus sunnah wal jama'ah) lebih disebabkan karena dua aspek ini; kebodohan terhadap konsep-konsep agama dan kemiskinan. ${ }^{15}$

\footnotetext{
2012), hIm. VII

${ }^{15}$ Asep Saifuddin Chalim, Membumikan Aswaja; Pegangan Para Guru NU (Khalista: Surabaya,
} 
Dengan demikian, para penganut Islam radikal yang biasa menggunakan cara-cara kekerasan dan aksi ekstrem lainnya untuk mencapai tujuan mereka, pada dasarnya dilatar belakangi karena kurangnya pemahaman mereka tentang Islam secara kaffah. Hal itu merupakan kenyataan mengingat gerakan radikalisasi agama sebenarnya tidak memiliki legitimasi yang kuat, karena tindakan-tindakan yang radikal tidak akan ditemukan akarnya di dalam teks al-Qur'an dan Hadist. Sehubungan dengan hal tersebut Mustafa Akhyol menyatakan:

\begin{abstract}
Hampir tidak ada satupun aturan-aturan detail dan larangan-larangan yang ekstrem sebagaimana saya lihat di beberapa buku-buku Islam ultra konservatif terdapat dalam al-Qur'an. Al-Qur'an pun berdiam diri terkait isu rajam para pezina, hukuman bagi yang mabuk-mabukan, atau membunuh mereka yang mengejek Islam. tidak ada juga sebutan Negara Islam, kekhalifahan global, atau polisi religious. Banyak yang saya lihat di dunia muslim dan tidak menyenangkan hati, saya sadar, itu semua karena tidak terdapat di dalam kitab suci Islam. ${ }^{16}$
\end{abstract}

Selain tidak memiliki dasar yang kuat dalam Islam, gerakan Islam radikal juga sangat berbahaya bagi kelangsungan kehidupan masyarakat berbangsa dan bernegara. Untuk itu, pendidikan yang dikelola dan dikembangkan $\mathrm{KH}$. Asep Saifuddin Chalim diantaranya bertujuan untuk menghindarkan para anak didiknya terlibat dalam gerakan radikalisme agama, seperti gerakan Hisbut Tahrir Indonesia (HTI). Dalam kaitan dengan hal itu Eko David menyatakan:

Kiai Asep melarang keras para santri Amanatul Ummah untuk ikut dalam organisasi HTI yang mengusung misi tegaknya Khilafah Islamiyah menggantikan pancasila sebagai dasar Negara dan falsafah bangsa. ${ }^{17}$

Menurut M. Syarif, sikap radikal merupakan sikap yang mendambakan perubahan secara total dan bersifat revolusioner dengan mengabaikan nilai-nilai yang ada, melalui cara-cara kekerasan dan aksi-aksi yang ekstrem lainnya. ${ }^{18}$ Selain itu, sikap radikal juga cenderung intoleran atau tidak menghargai pendapat dan keyakinan orang lain serta beranggapan bahwa dirinya merupakan pemegang kebenaran mutlak (truth claim). Jika sikap radikal dimiliki oleh seseorang maka akan berakibat pada perilaku yang menyalahkan dan membenci agama lain. Bahkan keyakinan yang demikian itu seringkali mendorong penganut agama untuk mengajak orang lain untuk pindah agama meskipun secara paksa. ${ }^{19}$

\footnotetext{
${ }^{16}$ Mustafa Akyol, op.cit., hal. 22

${ }^{17}$ Dikutip oleh Eko David SR, Kiai Asep Saifuddin Chalim, Lugas Bersikap, Luas Bercakap (Sidoarjo: Sarbikita Publishing, 2017), hlm. 98.

${ }^{18} \mathrm{M}$. Syarif, dkk. Pengembangan Ketrampilan Ibu-lbu PKK dalam Pencegahan Radikalisme di Kecamatan Pungging Mojokerto (Mojokerto: Laporan Hasil Pengabdian Masyarakat Program Studi Pendidikan Agama Islam Universitas Islam Majapahit, 2018), hal. 6

${ }^{19}$ Konawi Basyir, Pola Kerukunan Antar Umat Islam dan Hindu di Denpasar Bali. Jurnal Islmica, Vol. 8 No 1 tahun 2018.
} 
Sikap-sikap yang demikian itu tidak sesuai dengan prinsip-prinsip moderasi Islam yang diyakini oleh $\mathrm{KH}$. Asep Saifuddin Chalim, oleh karenanya beliau melarang siapapun yang me-ngaji padanya untuk ikut terlibat dalam oraganisasioraganisasi radikal. Larangan bagi setiap anak yang belajar ngaji kepada $\mathrm{KH}$. Asep Saifuddin Chalim untuk mengikuti organisasi Islam radikal seringkali disampaikannya kepada mereka dalam kesempatan pengajian sesudah shubuh, seperti pada saat ngaji kitab Mukhtarul Ahadis. Pada saat pengajian tersebut, $\mathrm{KH}$. Asep Saifuddin Chalim berpesan dan mewanti-wanti santrinya dengan pernyataan sebagai berikut:

Saya berpesan, saya mewanti-wanti santri Amanatul Ummah untuk menjauhi organisasi Hizbut Tahrir, saya juga mengutuk siapapun santri saya yang ikut Hizbut Tahrir. ${ }^{20}$

Tidak hanya terhadap santri yang masih aktif mengaji kepadanya, $\mathrm{KH}$. Asep Saifuddin Chalim juga sering memberikan peringatan kepada para alumni Pondok Pesantren Amanatul Ummah untuk menghindari gerakan Islam radikal seperti halnya HTI. Pernyataan Kiai Asep ini dikisahkan oleh pengurus pondok sekaligus pengurus ikatan alumni Amanatul Ummah yang menyatakan:

Pak yai sering mewanti-mewanti pada para alumni yang hadir agar tidak ikutikutan dalam organisasi HTI. Pak yai tidak rela ada santri, lebih-lebih lulusan Amanatul Ummah tergoda mengikuti aliran mereka. HTI ini bagian dari organisasi Islam trans-nasional, HTI tentu jadi ancaman bagi keberlangsungan Negara kita. Kita tak rela jika Negara yang dengan susah payah didirikan para pahlawan kita dikacaukan oleh ideology mereka. Santri Amanatul Ummah tidak boleh ikut mereka. ${ }^{21}$

Salah satu cara yang dapat dilakukan untuk mencegah peserta didik terlibat dan mengikuti aliran Islam radikal adalah dengan memberikan pendidikan Islam yang berkualitas bagi peserta didik. Hal itu merupakan aktivitas yang penting dan wajib diupayakan oleh guru, karena hal itu pada dasarnya merupakan tanggung jawabnya. Sehubungan dengan itu KH. Asep Saifuddin Chalim menyatakan:

Yang menjadi tanggung jawab para guru adalah mengentaskan mereka (warga nahdliyin) dari kemiskinan ilmu, khususnya ilmu yang pada akhirnya mampu membentengi mereka dari serbuan aliran yang bertentangan dengan aliran ahlus sunnah wal jama'ah. ${ }^{22}$

\footnotetext{
${ }^{20}$ Eko David SR, op.cit., hlm. 98-99.

${ }^{21}$ Hasil wawancara dengan Pengurus Pondok dan Guru Madrasah Bertaraf Internasional Amanatul Ummah (AU.03) pada tanggal 13 Januari 2018.

${ }^{22}$ Asep Saifuddin Chalim, Membumikan., op.cit., hIm. VII
} 
Dengan demikian diperlukan upaya yang serius oleh guru untuk melaksanakan pendidikan moderasi Islam, yaitu pendidikan yang mengajarkan prinsip-prinsip moderasi Islam, yang sesuai dengan ahlus sunnah wal jama'ah. Prinsip-prinsip tersebut sebagaimana yang juga diyakini oleh NU sebagai salah satu pergerakan Islam moderat di Indonesia. Dalam kaitan dengan tangung jawab guru dalam pendidikan moderasi Islam, KH. Asep Saifuddin Chalim menekankan peran guru dalam pernyataannya sebagai berikut:

Guru adalah ujung tombak satu-satunya dalam rangka menjaga, melestarikan dan membumikan eksistensi ajaran Aswaja pada masa yang akan datang, khususnya bagi kalangan Peserta Didik di lingkungan pendidikan formal. ${ }^{23}$

Tanggung jawab guru tidak hanya diemban ketika mereka berada di dalam kelas tetapi juga di luar kelas. Karenanya, di lembaga pendidikan Islam, yang dikelola dan dikembangkan oleh $\mathrm{KH}$. Asep Saifuddin Chalim terdapat program Dauroh (repetisi) yang dilaksanakan dengan pengawasan dan bimbingan Guru Pendamping. Selain itu, dalam sistem pendidikan yang dikelola KH. Asep Saifuddin Chalim, pencapaian target kompetensi Peserta Didik sepenuhnya merupakan tanggung jawab Guru Pendamping. Apabila terdapat Peserta Didik yang tidak dapat memenuhi target kompetensi, maka yang mendapat teguran adalah gurunya, bukan Peserta Didiknya, karenanya para guru harus berupaya keras mendampingi dan memotivasi para santri agar belajar lebih gigih hingga mencapai kompetensi yang diharapkan. ${ }^{24}$

Tanggung jawab pendidikan perlu dilaksanakan dengan pendekatan humanis dalam bingkai andragogi pendidikan. Dengan pendekatan ini, proses pendidikan dilaksanakan dengan mengacu pada upaya memanusiakan manusia. Adapun proses pembelajaran pada hakikatnya adalah proses tranfer pembelajaran sekaligus transfer nilai dan prinsip-prinsip kemanusian. ${ }^{25}$

Selain itu, pendidikan moderasi Islam juga diimplementasikan dengan pendekatan pengasuhan yang prinsip-prinsip tugasnya sebagaimana tugas orangtua di lingkungan keluarga, yaitu: 1) bertanggung jawab menyelamatkan faktor-faktor kasih sayang dari segala bentuk perilaku antagonis; 2) mengawal

\footnotetext{
${ }^{23}$ Asep Saifuddin Chalim, Membumikan., op.cit., hlm. VII

${ }^{24}$ Hasil wawancara dengan Guru Madrasah Bertaraf Internasional Amanatul Ummah (AU.03) pada tanggal 28 Agustus 2018.

${ }^{25}$ Asep Saifuddin Chalim, Konsepsi Lembaga Pendidikan Multikulturalis Menuju Masyarakat Madani Dalam Mengisi Kemerdekaan Indonesia. Makalah disampaikan dalam orasi ilmiah pengukuhan gelar Doktor Honoris Causa dari American World University di Singapura pada hari Sabtu, 25 September 2004. Sumber dokumen, Seh Sulhawi Rubba, Kiaji Asep Al-Amin, Kisah Mujahadah Ulama NU dalam Saham Dakwah Islam (Manggalarang: Garisi, 2007), hlm. 166
} 
proses pendidikan anak dan memberi batasan-batasan tingkah laku; 3) mengurangi segala bentuk perilaku yang berlebihan. ${ }^{26}$

Implementasi pendekatan pengasuhan dalam pendidikan sangat penting untuk diupayakan berdasarkan keyakinan bahwa melalui pengasuhan yang baik, akan lahir generasi terbaik yang menjadi penerus dan tumpuan masa depan. Keyakinan demikan sesuai dengan inspirasi al-Qur'an Surat An-Nisa' ayat 9, juga terbukti kebenarannya secara ilmiah melalui hasil penelitian Nick Stinnet dan Johnn De Frain dalam studinya yang berjudul "The National Studi on Family Strenght. Hasil penelitian tersebut menyimpulkan bahwa keluarga yang sehat dan bahagia (merupakan salah satu kriteria) yang memiliki peran signifikan bagi perkembangan kepribadian anak yang sehat. ${ }^{27}$

Oleh karena itu, sistem pendidikan yang dilaksanakan di lembaga-lembaga pendidikan, perlu mengimplementasikan konsep pengasuhan terbaik kepada peserta didik. KH. Asep Saifuddin Chalim menyatakan:

Dunia pendidikan... membutuhkan konsepsi pengasuhan ini sebagai kerangka acuan... Untuk itu, perlu diambil sebuah perspektif baru yang dapat dipakai sebagai alternatif bagi proses pendidikan anak-anak kita. ${ }^{28}$

Aktualisasi konsep pengasuhan dalam pendidikan moderasi Islam di sekolah atau madrasah berarti mengandaikan bahwa sekolah atau madrasah adalah seperti keluarga dimana yang bertindak sebagai anak adalah para peserta didik, sementara ayah dan ibu adalah para gurunya. Konsep pengasuhan yang demikian diimplementasikan oleh KH. Asep Saifuddin Chalim di Pondok Pesantren dan Madrasah Bertaraf Internasional Amanatul Ummah, diantaranya dengan cara menuntut para guru yang mengajar di lembaga tersebut dapat mempersepsikan peserta didik selayaknya anak-anak mereka sendiri, sehingga proses mendidik yang dilakukan akan berjalan dengan penuh keseriusan karena pada dasarnya orang tua sedang mempersiapkan anaknya untuk menjadi manusia berilmu dan berkualitas di masa mendatang. ${ }^{29}$

Selain harus mempersepsikan diri sebagai orangtua dalam memberikan proses pendidikan yang terbaik bagi Peserta Didiknya, implementasi konsep pengasuhan dalam pendidikan juga diaktualisasikan dalam bentuk memberikan

${ }^{26} \mathrm{Al}$-Qarashi, Baqir Syarif. 2003. Seni Mendidik Islami; Kiat-Kiat Menciptakan Generasi Unggul. Jakarta: Pustaka Zahra. 46

${ }^{27}$ Dikutip oleh Hawari, Al-Qur'an; ilmu kedokteran jiwa dan kesehatan jiwa (Yogyakarta: Dhana Bhakti Prima Yasa, 1997), hlm. 215

${ }^{28}$ Asep Saifuddin Chalim, Konsepsi. Makalah sebagaimana dokumentasi oleh Seh Sulhavi Rubba, op.cit., hlm. 159

${ }^{29}$ Hasil wawancara dengan K.H. Asep Saifuddin Chalim (AU.01) pada tanggal 13 April 2018. 
perhatian penuh, sebagaimana $\mathrm{KH}$. Asep Saifuddin Chalim juga sangat perhatian terhadap santrinya bahkan seoalah mengalahkan perhatian kepada anak kandungnya sendiri. ${ }^{30}$

Namun, mengingat Islam moderat adalah produk ijtihad yang belum memiliki prosedur operasional yang standart (SOP) untuk memandu implementasinya dalam kehidupan sehari-hari, maka pengajaran Islam moderat yang kontekstual tidak mudah. Bahkan sebaliknya akan sering menemui kendalakendala, diantaranya sebagian buku ajar mata pelajaran fiqh di madrasah memuat bahasan tentang Islam puritan seperti hukum potong tangan, qishah, rajam, jihad dan bahkan pendirian Negara Islam (khilafah).

Ironisnya, pembahasan masalah-masalah tersebut tidak disertai penjelasan bagaimana hukum-hukum tersebut dikontekstualisasikan dalam kerangka Islam Indonesia modern yang multikultural. Sangat disayangkan pula, pembahasan masalah tersebut tidak menyediakan pemikiran tentang hukum-hukum lain yang dapat dijadikan alternatif penerapan hukum yang efektif dan sesuai dengan sifat dasar dan prinsip-prinsip moralitas Islam.

B. Pendidikan Moderasi Islam untuk Mewujudkan Masyarakat Madani Indonesia

Tujuan akhir dari keseluruhan proses serta aktivitas pendidikan yang dikelola dan dikembangkan oleh $\mathrm{KH}$. Asep Saifuddin Chalim dengan berbagai aspek dan dimensinya pada prinsipnya adalah untuk mewujudkan masyarakat madani di Indonesia. Dalam kaitan itu KH. Asep Saifuddin Chalim menyatakan:

Konsepsi masyarakat madani adalah bangunan akhir yang hendak dicitacitakan oleh sistem dan mekanisme pendidikan alternatif. ${ }^{31}$

Menurut KH. Asep Saifuddin Chalim, ada banyak penjelasan mengenai konsep masyarakat madani, namun inti utama dari masyarakat madani adalah keberadaan masyarakat sipil yang selalu melakukan proses pencarian jati diri serta dijaminnya kebebasan individu untuk berkembang sesuai minat, bakat, afeksi, emosionalitas serta kemampuan kognisi yang melekat padanya, sehingga individu memiliki kemampuan dan peluang untuk membangun budaya kewargaan yang menjadi dasar bagi bangunan masyarakat madani. ${ }^{32}$

Konsepsi masyarakat madani menurut KH. Asep Saifuddin Chalim memiliki kesesuaian dengan konsepsi masyarakat madani menurut Hasan Hanafi. Bagi

\footnotetext{
${ }^{30} \mathrm{Hasil}$ wawancara dengan Pengasuh dan Kepala Madrasah Bertaraf Internasional Amanatul Ummah (AU.02) pada tanggal 13 Februari 2018.

${ }^{31}$ Asep Saifuddin Chalim, Konsepsi. Makalah sebagaimana dokumentasi Seh Sulhavi Rubba, op.cit., hlm. 165

${ }^{32}$ Ibid, hal. 65
} 
Hasan Hanafi masyakat madani adalah masyarakat yang berperadaban maju, dan dibangun berdasarkan tauhid dan nilai-nilai ketuhanan yang mengandung moral, yaitu bentuk masyarakat yang memiliki tiga prinsip, yaitu: 1) pembebasan kesadaran manusia, 2) kesejajaran manusia, dan 3) solidaritas sosial. ${ }^{33}$

Kesesuaian konsepsi masyarakat madani menurut pemikiran Hasan Hanafi dengan pemikiran $\mathrm{KH}$. Asep Saifuddin Chalim terletak pada hubungan kedua konsep tersebut yang saling mempengaruhi. Dengan demikian, dapat diasumsikan bahwa ciri-ciri masyarakat madani sebagaimana yang dinyatakan oleh Hasan Hanafi akan dapat terwujud manakala konsepsi masyarakat madani menurut $\mathrm{KH}$. Asep Saifuddin Chalim dapat diwujudkan.

Dengan kata lain, masyarakat berperadaban maju yang berdiri di atas nilainilai ketuhanan dan nilai-nilai moral kemanusiaan seperti kebebasan kesadaran, kesejajaran dan solidaritas sosial, hanya akan terwujud apabila di dalam masyarakat tersebut setiap individu dijamin kebebasannya untuk berkembang dan diberikan peluang untuk membangun budaya kewargaannya. Jika masyarakat tidak memiliki hal tersebut, maka sebuah masyarakat akan sulit menjadi masyarakat madani sebagaimana yang dicita-citakan.

Konsepsi masyarakat madani menurut KH. Asep Saifuddin Chalim juga memiliki kesesuaian dengan konsep masyarakat madani yang dirumuskan oleh Tim ICCCE UIN Jakarta. Dalam konsepsi Tim ICCCE UIN Jakarta, sebuah masyarakat dapat ditandai sebagai masyarakat madani manakala dapat menampilkan lima karakter, yaitu 1) free public sphere; 2) demokratis; 3) toleran; 4) pluralisme; dan 5) keadilan sosial. ${ }^{34}$

Konsepsi masyarakat madani sebagaimana yang diuraikan di atas merupakan cita-cita yang diupayakan KH. Asep Saifuddin Chalim agar dapat terwujud melalui serangkaian aktivitas pendidikan dengan berbagai aspek dan dimensinya. Beliau menyatakan:

Sinergitas semua elemen pendidikan alternatif bertumpu pada koperasi akomodasi dan toleransi. Sumber daya Siswa yang kritis-etis beserta penyelenggara pendidikan alternatif yang berupaya meletakkan dasar-dasar manajerial, diarahkan bagi terbangunnya masyarakat madani. ${ }^{35}$

\footnotetext{
${ }^{33}$ Hasan Hanafi, op.cit., hlm. 20.

${ }^{34}$ Tim ICCCE UIN Jakarta. Pendidikan Kewarganegaraan (Civic Education); Demokrasi, Hak Asasi Manusia dan Masyarakat Madani (edisi revisi) (Jakarta: ICCCE UIN Syarif Hidayatullah Jakarta Berkerja Sama dengan The Asia Foundation dan Prenamedia, 2003), hlm. 248-250.

${ }^{35}$ Asep Saifuddin Chalim, Konsepsi. Makalah sebagaimana dokumentasi Seh Sulhavi Rubba, op.cit., hlm. 166
} 
Dengan demikian, bangunan masyarakat madani merupakan cita-cita dan tujuan akhir yang hendak dicapai oleh keseluruhan elemen sumber daya manusia pendidikan yang dikelola KH. Asep Saifuddin Chalim. Adapun sasaran awal untuk mencapai hal tersebut diantaranya dengan mengimplementasikan sistem pendidikan yang mempertimbangkan unsur budaya yang menghormati pentingnya etika, estetika dan keberagamaan.

Dengan sistem pendidikan yang demikian itu, sasaran yang diharapkan dapat terwujud adalah lahirnya intelektual muda yang memiliki ketangguhan dan keunggulan, baik ketangguhan dan keunggulan pada aspek kognitif maupun ketangguhan dan keunggulan pada aspek afektif. Sehubungan dengan hal tersebut KH. Asep Saifuddin Chalim menyatakan sebagai berikut:

Pendidikan alternatif yang didesain khusus ini adalah sebuah lembaga yang diabadikan untuk mencetak intelektual muda yang tangguh dan unggul baik pada wilayah kognitif dan efektif. Ketangguhan dan keunggulan itu diupayakan secara sistemik dengan mempertimbangkan unsur budaya yang menaruh pentingnya etika, estetika dan wilayah religius sebagai sudut pandang dan titik awal setiap aktivitas menuju sasaran bangunan masyarakat madani. ${ }^{36}$

Unsur-unsur budaya yang mempertimbangkan etika, estetika dan religiusitas sebagai dasar implementasi sistem pendidikan yang dikelola dan dikembangkan oleh $\mathrm{KH}$. Asep Saifuddin Chalim, pada prinsipnya bersifat universal. Oleh karena itu, walaupun pendidikan yang dikelola dan dikembangkan oleh KH. Asep Saifuddin Chalim adalah Pendidikan Islam indonesia akan tetapi dalam prosesnya, pendidikan tersebut juga mengakomodir budaya pendidikan dari Timur Tengah dan juga Amerika, seperti program Muadalah; yaitu pemberian pembelajaran Pendidikan Agama Islam berbasis kurikulum Universitas al-Azhar Kairo, Mesir dan juga pembelajaran Mata Pelajaran Umum berbasis kurikulum nasional Indonesia dan Cambridge University. ${ }^{37}$

Begitupun juga walaupun KH. Asep Saifuddin Chalim adalah tokoh NU dan selalu berupaya untuk menjaga prinsip-prinsip ahlus sunnah wal jama'ah, namun KH. Asep Saifuddin Chalim tidak menginginkan Peserta Didiknya menjadi orangorang yang fanatik, bahkan fanatik terhadap NU sekalipun. Terkait sikap KH. Asep Saifuddin Chalim tersebut sebagaimana diceritakan responden sebagai berikut:

Ada seorang santri, mungkin karena saking fanatiknya dengan NU, membuat jaket dengan atribut Pondok Pesantren Amanatul Ummah dipadukan dengan symbol dan gambar Nahdlatul Ulama. Pak yai rupanya kurang berkenan. Beliau memanggil santri tersebut, mungkin dimarahi, karena pak yai tidak mau Pondok Pesantren yang ia pimpin dikaitkan secara langsung dengan NU. Mungkin pak

${ }^{36}$ Asep Saifuddin Chalim, Konsepsi, op.cit., hlm. 165.

${ }^{37}$ Hasil wawancara dengan salah satu pengelola Amanatul Ummah pada tanggal 28 Agustus 
yai berpendapat bahwa yang bisa belajar di Pondok Pesantren ini semua orang tidak terbatas hanya pada orang-orang NU. Artinya orang-orang selain NU, seperti Muhammadiyah, Persis atau ormas keagamaan lain boleh dan sangat dipersilahkan untuk mendaftar sebagai santri Amanatul Ummah. ${ }^{38}$

Bagi KH. Asep Saifuddin Chalim, semua anak yang belajar di lembaga Pendidikan Islam yang dipimpinnya memiliki kedudukan yang sama dan sejajar, terlepas darimana asal-usulnya, apakah berasal dari putra pejabat, konglomerat atau masyarakat biasa yang memiliki perekonomian menengah ke bawah. Semuanya diperlakukan sama. Dalam kaitan itu KH. Asep Saifuddin Chalim menyatakan:

Rata-rata orangtua Siswa MBI Madrasah Aliyah Amanatul Ummah Surabaya adalah pegawai swasta yang sangat peduli terhadap pendidikan yang harus dienyam anak-anak mereka. Meski ada di antara mereka yang dari golongan bawah dan golongan atas seperti buruh pabrik dan Dosen atau anggota DPRD termasuk kepala kepala MAN/kepala-kepala SMAN, serta direktur perusahaan, bahkan Bupati, namun yang terjadi pada latar belakang orangtua Siswa MBI, apapun latar belakang mereka, kesemuanya memiliki potensi untuk beritikad baik memberi peningkatan pendidikan bagi anak-anak mereka.

Sehingga, meski ada heterogenitas latar belakang orangtua Siswa, semua civitas lembaga pendidikan patut bersyukur bahwa heterogenitas itu justru makin menguatkan keberhasilannya.

Pengelolaan yang meyakinkan dengan dasar peningkatan kompetensi dan prestasi Siswa membuka ruang kepercayaan masyarakat dan orangtua Siswa untuk lebih memantapkan diri menuntaskan proses pendidikan bagi Siswa. ${ }^{39}$

Heterogenitas latar belakang anak didik yang belajar di lembaga Pendidikan Islam yang dipimpin oleh $\mathrm{KH}$. Asep Saifuddin Chalim tidak hanya berasal dari masyarakat nasional Indonesia, tetapi juga berasal dari beberapa Negara lain, termasuk berasal dari Afghanistan yang membawa ciri khas kebudayaan, kebiasaan, bahasa dan ritual agama yang berbeda dengan santrisantri Indonesia.

Walalupun berbeda, namun santri-santri dari luar negeri merasa diperlakukan dengan sangat baik, dengan penuh persahabatan dibimbing dan diarahkan menggunakan bahasa Indonesia yang tepat dalam percakapan seharihari baik di asrama, di tempat makan, di masjid, di kampus ataupun di tempat olah raga. ${ }^{40}$ Fenomena ini mensiratkan betapa keterbukaan sistem pendidikan yang

\footnotetext{
${ }^{38}$ Hasil wawancara dengan Pengurus Pondok dan Guru Madrasah Bertaraf Internasional Amanatul Ummah (AU.03) pada tanggal 13 Februari 2018.

${ }^{39}$ Asep Saifuddin Chalim, Persepsi Masyarakat terhadap Madrasah Bertaraf Internasional; Kajian Masyarakat Lokal dalam Pendekatan Relasi Sosial di MBI Madrasah Aliyah Amanatul Ummah Surabaya di Desa Kembang Belor Kecamatan Pacet Kabupaten Mojokerto (Desertasi). (Malang: Universitas Negeri Malang, 2004), hlm. 57-58

${ }^{40} \mathrm{Hasil}$ wawancara dengan Mahasiswa dan Santri (AU.07) pada tanggal 09 Desember 2017.
} 
dikelola dan dikembangkan oleh $\mathrm{KH}$. Asep Saifuddin Chalim mampu mengakomodir berbagai budaya masyarakat yang berbeda-beda secara toleran.

Fenomena tersebut terinspirasi dari sistem sosial Masyarakat Madinah yang telah dibangun oleh Rosululloh SAW setelah beliau duduk bersama dengan kepala suku-suku yang bertikai untuk menuntaskan perjanjian yang kemudian disebut dengan Piagam Madinah. Dengan perjanjian tersebut, dijamin hak-hak masyarakat untuk menjalankan agama dan adat istiadat mereka sendiri, menerapkan bagi semua warga Negara peraturan yang dirancang untuk menjaga perdamaian keseluruhan. ${ }^{41}$

Dengan perjanjian tersebut, kota madinah bersama-sama dengan seluruh penduduknya menjadi terhormat. Mereka berkewajiban mempertahankan kota madinah dan melindunginya dari setiap serangan yang datang dari luar. Anggota masyarakatnya harus bekerjasama antara sesama mereka guna menghormati segala hak dan kebebasan yang sudah disepakati bersama. ${ }^{42}$

\section{PENUTUP}

Sebagai bagian akhir dari tulisan ini terdapat beberapa hal yang perlu dicatat sebagai kesimpulan yaitu: pertama, pencegahan perilaku radikalisme agama melalui jalur pendidikan yang diupayakan oleh $\mathrm{KH}$. Asep Saifuddin Chalim diantaranya dilakukan dengan mengimplementasikan pendidikan Islam yang berkualitas bagi peserta didik. Pendidikan Islam yang dimaksud dalam hal ini adalah pendidikan yang mengajarkan Islam aswaja sebagaimana ajaran NU yang merupakan organisasi Islam moderat terbesar di Indonesia.

Untuk mencapai hal tersebut, para guru harus memiliki tanggung jawab lebih karena merekalah satu-satunya ujung tombak dalam rangka menjaga, melestarikan dan membumikan eksistensi ajaran aswaja pada masa yang akan datang. Maka guru dalam sistem pendidikan yang dikelola dan dikembangkan oleh $\mathrm{KH}$. Asep Saifuddin Chalim tidak hanya pengajar di kelas, tetapi juga bertindak sebagai pengawas dan pendamping siswa di dalam maupun di luar kelas.

Dalam mengimplementasikan tanggung jawabnya, guru wajib berupaya keras mendampingi dan memotivasi para siswa agar belajar lebih gigih sehingga mencapai kompetensi yang diharapkan. Oleh karena itu, apabila terdapat Peserta Didik yang

\footnotetext{
${ }^{41}$ Tamim Ansary, Destiny Disrupted; A History of the Word Through Islamic Eyes. Terjemah oleh Yuliani Liputo, Dari Puncak Bagdad; Sejarah Dunia Versi Islam (Jakarta: Zaman, 2010), hlm. 60

${ }^{42}$ Muhammad Syafii Antonio, Muhammad Saw; The Super Leader Super Manager (Jakarta: Takia Publishin \& ProLM Centre, 2009 ), hlm. 154
} 
tidak dapat memenuhi harapan yang dicita-citakan, maka seharusnya yang mendapat teguran adalah gurunya, bukan Peserta Didiknya.

Kedua, Keseluruhan aspek dan dimensi pendidikan moderasi Islam KH. Asep Saifuddin Chalim pada akhirnya bertujuan untuk mewujudkan masyarakat madani di Indonesia. Inti utama dari masyarakat madani yang diharapkan adalah masyarakat sipil yang selalu melakukan proses pencarian jati diri serta dijaminnya kebebasan individu untuk berkembang sehingga memiliki kemampuan dan peluang untuk membangun budaya kewargaan yang menjadi dasar bagi bangunan masyarakat madani.

Untuk mewujudkan hal tersebut, diantaranya dilakukan dengan mengupayakan implementasi sistem pendidikan yang didasarkan pada unsur-unsur budaya yang mempertimbangkan etika, estetika dan religiusitas. Jika hal tersebut dapat dilakukan maka pendidikan diyakini akan mampu mewujudkan lahirnya intelektual muda yang memiliki ketangguhan dan keunggulan, baik ketangguhan dan keunggulan pada aspek kognitif maupun afektif, yang kesemuanya merupakan titik awal menuju bangunan masyarakat madani.

Mengingat masyarakat madani merupakan substansi dan tujuan yang dicitacitakan oleh seluruh warga Negara Indonesia, maka proses pencapaian cita-cita tersebut merupakan tanggung jawab bersama seluruh elemen masyarakat Indonesia, baik pemerintah, masyarakat, maupun pengelola lembaga-lembaga pendidikan, baik lembaga pendidikan Islam Formal, Non Formal maupun Informal. Termasuk juga pengelola lembaga-lembaga lain yang memiliki fungsi sosial dan pembudayaan masyarakat.

Oleh karena salah satu upaya mewujudkan masyarakat madani di Indonesia adalah dengan cara mengimplementasikan pendidikan moderasi Islam, maka pemikiran pendidikan $\mathrm{KH}$. Asep Saifuddin Chalim pada dasarnya merupakan prototype pendidikan moderasi Islam yang dapat dikembangkan dan diimplementasikan oleh para pengelola lembaga-lembaga pendidikan islam yang memiliki cita-cita untuk dapat mencegah perilaku radikalisme agama dan mewujudkan masyarakat madani di Indinesia melalui jalur pendidikan.

Sebagai sebuah bentuk awal, prototype pendidikan moderasi $\mathrm{KH}$. Asep Saifuddin Chalim tentu masih perlu dikembangkan lebih lanjut diantaranya dalam konteks pengembangan kurikulum dan program pendidikan, materi pembelajaran, strategi pengajaran, manajemen dan lain-lain sehingga siap diimplementasikan secara operasional di lapangan. Upaya dimaksud perlu dilakukan secara serius dan konsisten 
sehingga dapat menghasilkan pendidikan yang berkualitas, yang dapat mencegah perilaku radikalisme agama dan mewujudkan masyarakat madani di Indonesia.

\section{DAFTAR PUSTAKA}

Akyol, Mustafa. 2014. Islam Tanpa Ekstremisme; Potret Seorang Muslim untuk Kebebasan. Jakarta: PT. Elex Media Komputindo.

Antonio, Muhammad Syafii. 2009. Muhammad SAW; The Super Leader Super Manager. Takia Publishin \& ProLM Centre.

Basyir, Konawi, 2018. Pola Kerukunan Antar Umat Islam dan Hindu di Denpasar Bali. Jurnal IsImica, Vol. 8 No 1 tahun 2018.

Chalim, Asep Saifuddin, 2004. Konsepsi Lembaga Pendidikan Multikulturalis Menuju Masyarakat Madani dalam Mengisi Kemerdekaan Indonesia. Makalah disampaikan pada Orasi Ilmiah ketika menerima gelar Doktor Honoris Causa dari American World University Singapura, September 25.

Chalim, Asep Saifuddin, 2012. Membumikan Aswaja; Pegangan Para Guru NU. Khalista: Surabaya.

Chalim, Asep Saifuddin. 2004. Persepsi Masyarakat terhadap Madrasah Bertaraf Internasional; Kajian Masyarakat Lokal dalam Pendekatan Relasi Sosial di MBI Madrasah Aliyah Amanatul Ummah Surabaya di Desa Kembang Belor Kecamatan Pacet Kabupaten Mojokerto. Desertasi. Malang: Universitas Merdeka Malang.

David, Eko. 2017. Kiai Asep Saifuddin Chalim, Lugas Bersikap, Luas Bercakap Sidoarjo: Sarbikita Publishing.

El Fadl, Khaled Abou, 2004. Atas Nama Tuhan; dari Fiqh Otoriter ke Fiqh Otoritatif. Terjemah R. Cecep Luqman Yasin. Jakarta: PT. Serambi Ilmu Semesta.

Hanafi, Hasan. 2003. Cakrawala Peradaban Global; Revolusi Islam untuk Globalisme, Pluralism dan Egaliterisme Antar Peradaban. Diterjemahkan oleh Muhammad Saiful Anam. Yogyakarta: IRCiSoD.

Harahap, Syahrin. 2006. Metodologi Studi Tokoh Pemikiran Islam. Jakarta: Istiqamah Mulya Press.

Ismail, Pesantren, Islam Moderat dan Etika Politik Dalam Perpsektif Pendidikan Islam. Prosiding $2^{\text {nd }}$ Annual Conference For Muslim Scholerss (AnCoMS) Kopertais Wilayah 4 Surabaya tahun 2018,

Langgulung, Hasan. 2003. Asas-Asas Pendidikan Islam. Jakarta: Pustaka al-Husna. 
Lewis, David Levering, 2012. The Greatness of Al-Andalus; Ketika Islam Mewarnai Peradaban Barat. Terjemah Yuliani Liputo. Jakarta: PT. Serambi Ilmu Semesta.

M. Syarif, dkk. 2018. Pengembangan Ketrampilan Ibu-lbu PKK dalam Pencegahan Radikalisme di Kecamatan Pungging Mojokerto. Laporan Hasil Pengabdian Masyarakat Program Studi Pendidikan Agama Islam Universitas Islam Majapahit.

Mahfudz, Moh. 2018. Penguatan Moderasi Islam dalam Konteks Berbangsa dan Bernegara; Tinjauan Aspek Hukum dan Konstitusi. Makalah disampaikan pada $2^{\text {nd }}$ Annual Conference for Muslim Scholerss (AnCoMS) Kopertais Wilayah 4 Surabaya, April 21, UIN Sunan Ampel Surabaya.

RI, Departemen Agama, 1998. Al-Quran dan Terjemahnya (Surabaya: Al-Hidayah, 1998), hal. 36

Rozi, Syaikhu, 2018. Pendidikan Moderasi Islam Menurut KH. Asep Saifuddin Chalim. Laporan Akademik Bantuan Penelitian Diktis Kemenag RI Tahun 2018, FAI Universitas Islam Majapahit.

Suprayogo, Imam \& Tobroni. 2001. Metodologi Penelitian Sosial Agama. Bandung: PT. Remaja Rosda Karya.

Tim ICCCE UIN Jakarta. 2003. Pendidikan Kewarganegaraan (Civic Education); Demokrasi, Hak Asasi Manusia dan Masyarakat Madani, (edisi revisi). Jakarta: ICCCE UIN Syarif Hidayatullah Jakarta Berkerja Sama dengan The Asia Foundation dan Prenamedia. 